\title{
Projecting at the project-level: MMC supply chain integration roadmap for small housebuilders
}

Article

Accepted Version

Dowsett, R., Green, M., Sexton, M. and Harty, C. (2019) Projecting at the project-level: MMC supply chain integration roadmap for small housebuilders. Construction Innovation: Information, Process, Management, 19 (2). pp. 193-211. ISSN 1471-4175 doi: https://doi.org/10.1108/Cl-07-2017-0059 Available at https://centaur.reading.ac.uk/83384/

It is advisable to refer to the publisher's version if you intend to cite from the work. See Guidance on citing.

To link to this article DOI: http://dx.doi.org/10.1108/CI-07-2017-0059

Publisher: Emerald Publishing Limited

All outputs in CentAUR are protected by Intellectual Property Rights law, including copyright law. Copyright and IPR is retained by the creators or other copyright holders. Terms and conditions for use of this material are defined in the End User Agreement.

www.reading.ac.uk/centaur 
Central Archive at the University of Reading

Reading's research outputs online 


\section{Projecting at the project-level: MMC supply chain integration roadmap for small housebuilders}

\begin{tabular}{|r|l|}
\hline Journal: & Construction Innovation: Information, Process, Management \\
\hline Manuscript ID & CI-07-2017-0059.R2 \\
\hline Manuscript Type: & Research Article \\
\hline Keywords: & $\begin{array}{l}\text { Housing, Innovation, SME-s, Construction Management, Roadmapping, } \\
\text { Supply Chain Integration }\end{array}$ \\
\hline \multicolumn{2}{|l}{} \\
\hline
\end{tabular}




\title{
Projecting at the project-level: MMC supply chain integration roadmap for small housebuilders
}

\begin{abstract}
Purpose - This paper provides insights into how supply chain integration may occur for small housebuilders adopting Modern Methods of Construction (MMC). The process of creating an empirically informed road map is described whereby the practical day-to-day challenges of adopting a timber-frame solution on a small housing development in South East England were fed into a road map of future supply chain integration scenrios. The intention is to better position small housebuilders to contribute in addressing the shortfall in housing that continues to face the UK.
\end{abstract}

\section{Design/methodology/approach}

Interviews with supply chain members along with on-site observations captured key aspects of integration. Findings were used within two collaborative forums to guide discussion in a dual approach; discussing the challenges of timber-frame on the project, and what would be needed on future projects for the firms analysed.

\section{Findings}

Empirically informed malleable roadmaps, of the kind developed within this study, provide feasible options for small house builders and suppliers of MMC to collectively collaborate when transitioning toward fully integrated supply chains. Practically, the roadmapping approach, and the roadmap itself, would help small house builders and suppliers of MMCs transition towards full integration. Opening up avenues of integration that are spread across yet connected through numerous phases, firms, and technologies helps construction professionals use more sophisticated modular and volumetric off-site solutions.

\section{Research limitations/implications}

Data collection took place over the course of a year. Future research could expand this relatively short duration in order to analyse the potential for construction professionals within the supply chain to integrate further over a longer period of time.

\section{Originality/value}

The novelty and contribution of this paper lie in the development and application of an alternative approach to roadmapping that departs from the normative linear examples of roadmaps found within the technology-roadmapping (TRM) literature. We present a structured yet flexible approach to roadmapping that is both representative of the strategic planning and innovation activities that occur 
within small housebuilding firms, and open to adaption in order to account for firm level characteristics and contingencies. Positioned alongside firm-level dynamics (e.g. business cases and approaches to design) the roadmapping approach also reinforces the potential of incremental rather than wholescale transitions.

Keywords: timber-frame, small house builder, MMC, roadmap, supply chain integration

\section{Introduction:}

The residential construction sector at present is largely dominated by volume housebuilders whose economies of scale favour large green-field sites where standardised and repeatable homes can be constructed quickly and cheaply. Yet there is still a significant undersupply of housing and it is estimated that 225,000 to 275,000 or more homes per year are required to keep up with demand in England (DCLG 2017). It is also estimated that an additional 25,000 homes can be built each year by SME housebuilders if the number operating in the market can return to 2007 levels of around 6000 (HBF 2017). Until now the role of small and medium (SME) housebuilders in the construction of new housing in England has gradually declined from over 10,000 in 1980, building 57 percent of all housing, to 2,800 in 2014, building only 27 percent of all output (Archer and Cole 2016). A number of reasons for this decline exist predominantly relating to planning and financing that significantly influenced the shape of the market in favour of larger housebuilders (HBF 2017). Consequently, there is now a drive to diversify the market and re-establish SME house builders, whose business models favour small brownfield sites, as significant contributors to closing the demand-supply gap.

The 2017 Government White Paper, 'Fixing our broken housing market', acknowledges this problem clearly stating that the undersupply of housing is not a problem of 'not enough space' but more so an issue with planning, a slow construction process, and a market reliant on a small number of large volumetric housebuilders. Consequently, we are now seeing a shift in policy direction favouring brownfield development that supports the business practices of SME housebuilders through the provision of government lending schemes and relaxation of planning charges.

These state-led policy initiatives seek to improve market entry conditions for SME housebuilders and re-establish their position at the forefront of the residential construction sector. They also draw attention to the operational aspects of housebuilding and prioritise the use of modern methods of construction (MMCs), implicitly proposing a new future scenario for UK residential construction where the number of SMEs delivering housing using MMCs is greatly increased. This paper argues that although the antecedent conditions for market entry have been rebalanced in favour of SMEs based on past and present understanding of the planning system, and 'the market' as a whole - a more granular understanding of the implications of adopting MMCs across supply chains is required. It is 
our contention that this has the potential to open up further avenues of supply chain integration for SMEs and therefore implement MMCs more effectively.

MMCs and the technologies they are comprised of require changes to the existing business processes and practices of SME house builders and their supply chain that are under acknowledged in industry and governmental publications (Pan et al. 2007). Here, futures of housebuilding for SMEs have been decontextualized from the processes of small-scale housebuilding and the number of supply chain interfaces that need to be reconfigured in order to adopt MMCs.

More attention should be paid to the specificities of MMC adoption by small housebuilders to better represent the context of implementation and inform the facilitating conditions for increasing uptake. This paper aims to tackle this problematic by presenting an empirical case of a small housebuilder utilising timber-frame; the day-to-day challenges and instances of supply chain integration as they happened on this project are discussed concurrently to the process of developing a roadmap for future supply chain integration. Roadmapping is presented as an approach to consider and capture opportunities to innovate specific to SMEs (e.g. Savioz and Blum 2002) and framed as structured yet flexible to accomodate contextual contingencies. The intention being, to establish a stronger association between the roadmap and the evolving and adapting configurations of integration that occur to inform its content. The strategic lens through which the normative and dominant approaches to roadmapping are framed is challenged but more pertinently the applicability of these approaches to small housebuilders as a strategic planning method. By drawing on the construction innovation literature, in particular that which pertains to SMEs, we develop fresh insights into how roadmaps can be operationalised. Thereby making a contribution to the broader roadmapping literature whilst concurrently capturing how supply chain integration (and the discrete innovations that can constitute it) occurs across the supply chain of a small housebuilding project.

This paper is structured as follows: first, an overview of the challenges and constraints faced by small housebuilders in their attempt to adopt and implement MMCs is discussed that elaborates on the wider contextual issues relating to supply chain integration. Secondly, the utility of roadmaps and the process of roadmapping as an approach to exploring supply chain integration potentialities are discussed, situating the research approach in relation to the context of housebuilding for SMEs. Subsequently, the case and research methodology are described and are followed by the findings, and discussion and conclusion.

\section{MMC housebuilding for SMEs}

Current research into technology implementation and innovation diffusion within construction firms demonstrates that the process of implementing innovation is distinctly different within SMEs than it is in larger organisations (Sexton and Barrett 2003; Barrett and Sexton 2006). In postulating potential constraints for SME's to innovate, Sexton and Barrett (2003) show that approaches to innovation 
taken by small firms relates to specific organisational characteristics and capacities. Attention is consequently needed when designing strategies of innovation that are appropriate to firm level characteristics. Innovation strategies - such as those presented in roadmaps - need to be appropriate to the specific challenges and opportunities that smaller organisations face.

In contrast to larger construction firms, SMEs have less absorptive capacity (Upstill-Goddard et al. 2016), whereby the extent that firms can incorporate external knowledge in order to innovate is restrained by the skills, training and experience of their smaller human capital (Muscio 2007). Housebuilding adds a further distinction between the innovative practices of SMEs and large organisations whereby the greater amount of capital available enables them to build on larger sites and have more resources to standardise homes that are more suited to prefabrication. The initial adoption of innovations within SMEs is generally motivated by an economic necessity to stay in business but as Abbott et al. (2006) show, if absorptive capacity can be increased developmental innovation as a proactive activity becomes embedded within an organisation thereby increasing their capability to implement more ambitious innovations.

At a practical level however there is little guidance for SME housebuilders as to how they might go about adopting MMCs in their business practices based on their current processes. Such processes include the size of developments that are feasible for SME housebuilders whereby the economies of scale required for standardisation and modularisation of building components are less viable - than volume housebuilders - due to business models centring on bespoke housing designs. Procuring sites with planning permission approved can also dictate the design requirements of the homes built. Access for heavy lifting equipment required for building with MMCs is also more difficult on smaller sites. Furthermore, the use of subcontractors makes it difficult to innovate in a proprietary way as compared to large volume housebuilders (Asibong and Barlow 1997), but as Green et al. (2017) argue, it is this distinctiveness of supply chain relationships that needs to be examined in order to innovate within the context of small-scale housing developments.

\section{Road mapping for SMEs}

SME house builders are now presented with a relatively well-defined future market opportunity/scenario that requires a very different mode of operation to those currently in place but limited insight into how they might move toward it. Further, strategic planning within SMEs across all industries is consistently shown to be lacking (Wang et al. 2007) for reasons of market instability and resourcing and therefore lack what could be considered the appropriate skills and knowledge to plan a strategy of supply chain integration to successfully compete in a newly redefined market (Stonehouse and Pemberton 2002).

Despite road mapping having the potential to aid the systemic level of reconfiguration that is needed for SMEs, research relating to road mapping either neglects or is not appropriate for them. Research 
often focuses on issues pertinent to large firms such as aligning research and development structures with product development structures (Caetano and Amaral 2011). Furthermore, technology roadmaps often foreground strategy creation - and neglect operational uses of roadmaps - which suits larger enterprises developing particular products (Savioz and Blum 2002). The emphasis given to strategies rather than operational aspects is also less useful for SMEs whose work often includes short term projects (Probert and Shehabuddeen 1999). Current approaches to roadmaps are rarely suitable for SMEs as they fail to take into consideration the distinct processes that characterise SMEs and thus also ignore their strengths (Savioz and Blum 2002).

\section{Road mapping for small to medium house builders}

The lack of fit between approaches to roadmaps and the organisational structures of SMEs is of particular significance to SMEs in construction. There is a relative lack of road mapping in the public domain for construction as a whole than many other industries (see Amer and Daim (2010) for an overview of roadmaps in the public domain). Road maps designed for housebuilders often get lost in translation when applied in the context of small to medium housebuilders due to fact that they were created for and by volume housebuilders. The following section attends to the problem of trying to project a future without fully understanding the characteristics of the work that is undertaken, and builds on the acknowledgment that road maps need to be tailored specifically for SMEs for courses of action to be feasible. In order to do so we take a 'step back' and think through the implicit trajectories that are embedded into roadmaps.

\section{Approaching road mapping}

As detailed above strategic planning requires attention to align strategies to firm level strategies, and in the case of housebuilding in the UK, strategic planning needs to take into considerations the constraints and opportunities for small housebuilders to transition towards using MMCs. Road mapping as an approach to strategic planning has become increasingly popular over recent decades (Phaal et al. 2004; Phaal et al. 2010; Phaal et al. 2013). In the following, we reveal some of the potential ways that roadmaps have been framed at firm, industry, and market levels, before detailing how they may aid transitions to MMCs for small housebuilders in the UK.

The term roadmap is widely - and often vaguely - used (Loureiro et al. 2010). Broadly speaking road mapping is an approach to strategic planning whereby long term objectives are envisioned and routes of transitioning toward such objectives suggested (Albright and Kappel 2003). In the words of Phaal et al. (2010):

"In essence, roadmaps are simple, adaptable 'strategic lenses' through which the evolution of complex systems can be viewed, supporting dialogue, alignment and consensus." (Phaal et al. 2010:

2) 
Phaal continues to explain how Motorola, as early exemplars of roadmaps in 1970s, famously aligned technological advances - such as display technologies and possibilities of tuning - with particular products for the coming decade. Since Motorola initiated and illustrated the potential benefits of roadmaps to align trajectories of technologies and products, the use of roadmaps has continued to aid strategic planning at a variety of levels including firms, industries, and policies. For the purpose of this paper it is important to build on Phaal's (2010) assertion that roadmaps feed into complex systems, and as such it is important to unpack how roadmaps incorporate wider contexts and thus require adaptability.

What constitutes the system that roadmaps attend to varies dramatically. Roadmaps can relate to industrial trends and the planning of new products or services (Oliveira and Rozenfeld 2010), managing technological processes in relation to economic and social contexts in order to make the most of opportunities that markets may provide (Rocha and Mello 2016). In this context, projections of markets and of technologies as a whole are used to redesign products to align market and technological trends. Others have focused more specifically on facilitating the support for particular technologies through adaptions such as the implementation of IT platforms to ease the development of technologies (Lee and Park 2005). Yet for project-based companies such as house-builders who focus just as much on the process of construction as the product itself, the saliency of roadmaps relates less to how markets may be characterised in the future or which technologies are going to be available, but more so on how they can improve their products and processes through implementing different technologies and tailoring these to fit particular projects.

\section{Flexible integration: road mapping with multiple construction professionals}

Despite an acknowledgement that partnerships need to be taken into account when creating roadmaps, research on technology road mapping has only scratched the surface of the implications of these arrangements (Wells et al. 2004; Gerdsri et al. 2009) where emphasis has been given to selecting partners (Lichtenthaler 2010; Lee, Yoon, Lee and Park 2009; Daim and Oliver 2008). Little effort has thus been given to the variety of work that different partners specialise in (Caetano and Amaral 2011). When taking into consideration the unique problematics for small house builders managing multiple subcontracted trades on short-term projects, together with skill bases shifting partially to manufacturing phases when building with modern methods of construction, more work is needed to consider the variety of intersecting activities that require adaptation (Caetano and Amaral 2011).

Considering these intersections means recognising the current forms of integration between supply chain members and the types of adaptations to individual firm processes that are necessary to achieve a desired form of integration. Within this paper emphasis is placed on achieving a 'desired form of integration' as opposed to a prescribed level to acknowledge discussions made within the literature 
around the varying absorptive capacity of firms within SME project teams (Abbott et al, 2006; Barrett and Sexton, 2003).

In light of the preceding literature, the approach to road mapping adopted within this research project departs from normative approaches that position technology innovation as linear and prescriptive and builds upon Phaal's (2010) recommendation that roadmaps should be adaptable. We argue that the destination or form of integration that a supply chain targets toward should be defined by the categories of adaptation needed to reach them and the current capability of the firms to do so. In other words, roadmaps for SMEs using MMCs should not propose linear progression through stages of integration nor prescribe them. The key to unlocking the utility of roadmaps for SMEs, we argue, is adaptability and flexibility in structure so that the route taken to achieve the desired form of integration can be modified according to an interplay between project-level objectives and firm capabilities to innovate. In the process of developing the roadmap practitioners are acquiring, amalgamating, and storing collective information, to produce 'a product depicting space peculiar to a moment in time' (Paulston and Liebman 2016) from which to make projections of future supply chain integration scenarios.

\section{Method}

This research was primarily concerned with understanding how actors and firms within the supply chain interacted throughout the construction of the four timber-frame houses, and the implications of these interactions on the completion of supply chain partner tasks, as well as the delivery of the development as a whole. Necessarily this involves the examination of context-dependent knowledge and as such, an interpretivist case-study approach - as advocated by Flyvbjerg (2006) - in which particular issues are studied in detail and from the perspective of the actors involved to draw lessons, was adopted. Case study research has been criticised on the basis that it is not possible to generalise from an individual case and that they contain biases toward verification. Conversely, Flyvberg strongly defends the value of single-case study research arguing that formal generalisation is overvalued compared to the 'force of example' and that it is possible to generalise from a single-case study by providing, for example, a counter-example to normative beliefs and assumptions. Further, rather than a bias toward verification, case studies tend toward falsification since the complexity of cases and the depth and intensity to which they are examined are likely to challenge researcher preconceptions.

The research described in this paper reflects this approach: the researchers spent a significant amount of effort building up relationships with both the onsite and offsite team to collect a large amount of data using a variety of techniques to examine the process and context of implementing timber-frame as an innovation on small housing developments. 


\section{The case: Percy's Yard}

An Innovate UK-funded research project led by the house-builder in collaboration with the timberframe supplier and the academic research team provided the circumstances of empirical data collection As detailed in the literature review there is a longstanding shortfall in the supply of housing in UK of which building on brown field land, utilising off-site methods of construction, and facilitating SME construction firms is often cited as a solution. 'Percy's Yard' was chosen as a representative case that includes all three of these characteristics.

The case centres on a small housing development of five units in South East England, four of which built using open panel timber-frames. 'Percy's Yard' is the first site on which the house-builder has used this method of construction. The strategic aim to adopt timber-frame was to capitalise on more stringent performance requirements of new homes and minimise risk to the project's programme by reducing their reliance on bricklayers. Percy's Yard was also in close vicinity to other existing dwellings buildings resulting in restricted access to the site. Utilising off-site methods overcame some of the access challenges by reducing the amount of deliveries to site and time on site in general. The challenges pertinent to Percy's Yard were typical that many others can learn from, the case study helped to develop potential recommendations of how SME's can integrate with off-site suppliers across a number of different phases/activities.

\section{Data collection techniques}

Empirical work took place over the course of a year involving extended periods of observation, analysis of project documents such as programs of work, and interviews with supply-chain members. Participants included managing directors, designers of the timber-frame, the installation team, the site manager and assistant site manager, carpenters, and subcontracted trades such as plasterers, bricklayers and carpenters (Table 1). Strict adherence to the principles expressed in the University of Reading research ethics framework, particularly those regarding participant and firm anonymity, was kept throughout the data collection process. Each of the data collection techniques are discussed below.

\section{Observations}

Field notes were used to capture important aspects observed by the researcher in both on and off site project activities, including informal discussions with site personnel and visits to the timber-frame factory. These were neither standardised nor used explicitly for data analysis but used as points of discussion within interviews to stimulate more in-depth responses from participants and further understanding of the problems the team faced. 


\section{Interviews}

Purposive and sequential sampling was employed to locate 'information-rich' informants to ensure an information-rich case (Patton, 2002) whereby participants were selected, where possible, based on their experience of integrating SME housebuilders with MMCs. When initially selecting participants the research team worked alongside the project partners to identify roles pertinent to the challenge of integrating SMEs with timber-frame suppliers, and secondly to select participants who had experience of this challenge. For example, as noted earlier, the role of subcontractors such as electricians and bricklayers is crucial to the overall build out of MMC and as such subcontractors were included in the sampling criteria.

Interviews were semi-structured and designed to explore participants' previous experience of working with different construction professionals, experience of working on Percy's Yard, and reflections on how and why forms of integration were or were not possible. Interviews were conducted prior to the installation of the timber-frames, throughout the build-out, and once the development was complete. Follow up interviews encouraged reflection on initial findings from Percy's Yard and how integration could occur differently on future developments and through firm level adaptations.

\section{[Insert Table 1]}

\section{Collaborative forums}

Throughout the duration of the project findings were shared with the project partners as were drafts of the road map created. Collaboration occurred through quarterly meetings, regular contact via email and telephone, and two sandpits/forums. The sandpits/forums enhanced the suitability and relevance of the findings (Broadley et al. 2016) by both presenting findings to the research partners and encouraging the co-creation of potential avenues of integration in the future.

Attended by the site manager, managing directors, installation managers, and architect, the first sand pit/forum focused on concerns and queries surrounding Percy's Yard. The second sand pit/forum focused on the design considerations for suppliers and small house builders and was attended by members of the design team based at the timber-frame suppliers.

\section{Analysis and interpretation}

To enable understanding and interpretation of what was happening within these forums prior knowledge of the context of study was developed through a concurrent review of the literature, consistent with the idea that observation is 'theory-laden' (Hanson 1958) and always shaped by the concepts in the mind of the observer (Winch 1958). Following Ritchie et al (2013) our analysis was continuous and iterative as we frequently moved between stages of managing and making sense of the data. In terms of the former, potential themes were identified while the latter focused on analysing the themes in relation to the data as a whole and on the saliency of the themes for all research partners. 


\section{Collaborative trajectories: an evolving roadmap}

From the outset of the research project, all actors were aware that one of the outputs of the research would be a roadmap. The structure of the roadmap was however open for discussion. Despite consensus that it would have the aim of strategically planning how small house builders and timberframe suppliers could adapt processes to ease and improve the construction of timber-frame houses, the following findings illustrate how the categories and the axis - fragmented, partial, and full integration - came to structure the roadmap (see: Figure 1). Following this the 'indicative manual' created by the team shows how the empirical data was used to populate the roadmap. Here projections of future supply integration scenarios and retrospective assertions of a fragmented supply chain in areas where they had integrated on the project are provided. We then discuss the implications of putting projects into projections through the creation and adaption of empirically informed roadmaps.

\section{Axis of integration: supply chain status}

Drawing on both the roadmap literature (e.g. Phaal et al. 2013; Kappel 2001) and the empirics of the case, three indicative stages of supply chain status were elected to form the axis of integration: fragmented (where they are now), partially integrated (steps taken to move toward a future state), and fully integrated (where they want to be). This was to account for the distinct characteristics of each firm - in terms of business processes - and emphasise that the effectiveness of the roadmap relies on an appropriate balance between the capabilities of each firm and the activities necessary for integration. In other words, for the project partners to gain any real value from the roadmap, flexibility and customisation were important features to include, allowing them to negotiate collective strategic milestones relative to their own commercial and technological perspectives. Therefore an important feature of the roadmap is to present different forms of integration that present that overall route of integration taken throughout the project and to highlight areas for focussing on improvement relative to firm capability.

\section{Sandpit Stage-Gates:}

Prior to the delivery and installation of the timber-frames onsite, the team participated in a collaborative forum - loosely based on a sandpit methodology - to review and discuss project progress. Within the 'sandpit', project members reviewed aspects of the design, installation, and build-out stages of the timber-frame houses that could potentially be problematic, discussing them in relation to the efficacy of planned onsite activities. This proved invaluable to the onsite team in that it gave them the opportunity to qualify their understanding of the process of erecting a timber-frame structure, query their planned approach to tackle onsite tasks, and decide upon a more pragmatic course of action informed by the collective expertise of the project team. The positive experience of the installation prompted the team to include a further three sandpit stage-gates within the roadmap. 


\section{Threading and rethreading integration}

In the context of the roadmap, these sandpit stage-gates serve as a designated collaborative space, facilitating dialogue that is productive and requisite to collective decision-making around the route taken to move toward an integrated supply chain. Timed prior to major project phases so that meaningful interventions can occur, these stage-gates are identified as design, installation, build-out, and post-project. The reasoning behind this is that these are the stages at which new stakeholders are introduced bringing new experience and knowledge that must be thread into projections of future integration activities, or at later stages - based on their experience throughout the project- rethread to make new projections of integration activities. This incorporates reflexivity into the roadmapping process centred on the experiential knowledge within the project team as a collective, balancing technical considerations and market potential against the project context and the capabilities of the firms involved. The intended benefits of doing so are to make clear, and therefore, better manage expectations and perceptions around the process of integration. In doing so, flexibility and adaptability is given precedence over the perceived linearity, discipline and thoroughness of more prescriptive examples of roadmapping processes to respond to potential risks and therefore determine appropriate mechanisms and management approaches for the deployment of integration activities.

\section{Project phases}

The roadmap is divided into the five distinct yet interdependent phases of the timber-frame housing project. Each project phase constitutes a distinct configuration of the project team where one member's expertise will dominate and in some way dictate the activities of the others to deliver the tasks necessary to complete that phase. By making the distinction between these project phases the team were able to populate the 'boxes' with the empirical findings gathered from on-site activities, observations, and interviews providing a graphical overview of how a small scale timber frame housing development progresses (see Figure 1). Project partners were then able to situate themselves visually within a wider context of the project, using this as a frame of reference to consider the impact of upstream activities on their own process and the impact of their own processes on downstream activities. This prompted more meaningful and realistic discussion, based on their current ways of working, around future projections of integration. The project phases are described in the following section using examples from the empirical data and elaborates within five vignettes how the team discussed onsite implications in relation to their current capabilities to come to pragmatic potentialities for future supply chain integration scenarios.

\section{[Insert Figure 1]}




\section{Benchmark zero: Putting projects into projections}

The key objective of the roadmap was to provide an overview of potential options for the project partners to integrate further and to allow them to identity adaptions within and across project phases at the same time as making considerations for the overall supply chain when doing so; linking the commercial and technological perspectives of each firm. Used in conjunction with the project phases this allowed project team members to reflect on the status of their supply chain as it currently was agreeing an assumed starting point as fragmented with some areas of partial integration (see Figure 2). As the case study findings show, adaptions to supply chain integration occurred at different points throughout the project phases and varied in extent depending on the firms and their capacities.

\section{Business Case:}

The significance of providing a separate phase to describe the business case for each integration phase draws on the literature regarding how the distinct organisational capabilities of small firms defines their ability to innovate (see Barrett and Sexton, 2003; 2006). It was also informed by the specific circumstances of the case and how the type of procurement method employed on the case project defined the extent to which the supply chain was able to integrate.

\section{Vignette 1: The implications of contradictory procurement strategies}

To allow an appropriate time for project programme planning, the housebuilder needed to secure the relevant trades in advance. Conversely, the timber frame contractor operates however on just-in-time principles, where they finalise the design of the timber-frame two-weeks prior to delivery onsite. Their rationale for operating in this way is to avoid interrupting factory processes when clients make late design changes. This approach, based on experience of working on one off builds, was standardized across the firm but created problems for actors employed by the house builder.

To ensure project progress, trade tenders had to be made from the architectural drawings rather than the finalised timber frame drawings. Onsite problems occurred when it was revealed that the timber frame designers had specified a steel beam to run through one of the first floors of one of the plots to accommodate the large span designed by the architect. The implications of which were that the services had to be rerouted around the steel beam creating additional unanticipated work for each trade with the risk of cumulatively adding cost to the project.

The delivery of off-site timber frame housing lends itself to more integrated procurement methods such as partnering. However, the characteristics of these methods - such as long-term relationships conflict with the existing business models and operational actions of small housebuilders and their supply chain and so the team began to discuss ways in which to transition toward a fully integrated supply chain. When discussing the business case and potential future projections solutions the team tended to refer to procurement mechanisms most suited for large-scale firms. However, it was quickly 
realised that whilst these were useful discussion points that drew out the key value-adding principles of supply-chain partnering, these mechanisms in their normative definition were not suitable for smaller housebuilders, and whilst included into the roadmap they were further defined in more widely applicable terms (see Figure 1). This centred on the consensus that communicating the business benefits of supply chain integration to deliver timber frame housing is particularly important for small housebuilders and fed into discussions around resolving tensions between the procurement method employed by the housebuilder and the design and supply method of the timber frame contractor.

\section{Design}

Experience of designing with off-site timber-frame amongst the design team is important for the successful delivery of a project. Design for manufacture (DfMA) requires an understanding of the prefabrication process, more specifically the early receipt of complete information. This is predicated on a collaborative design process where design intent and information requirements are clearly communicated. The following vignette shows how the team used the onsite implications of the procurement method to discuss the design process and proffer potential future solutions at the level of SMEs when full-scale partnering cannot be achieved.

\section{Vignette 2: Design process conflict}

Whilst the tension between business processes provided the situation for the steel beam issue to arise, it was not, in and of itself, the cause of onsite changes. The conflict between the design method of the timber frame contractors and the traditional project procurement method exposed areas elsewhere in the project phases to consider for integration. This vignette focusses on the information flow and design process conflict that led to the inclusion of the steel beam.

The timber frame contractors design the timber-frame from the architects drawing, redrawing the design according to the structural requirements of timber-frame. This included a steel beam in one of the plots. In a traditional brick and block design process changes such as this tend to be made by the architect and are signed off based on final sum rather than interpretation of the drawings. This process was overlaid onto this project and the existence of the steel beam was only realised during installation. As the timber frame designer described:

"Normally there's, with my experience, they don't really take a lot of time to look at details on the drawing, they just see the big letters at the bottom and just sign them"

Not only did this create issues for first fix services, in that they had to be rerouted this also became an issue for the tackers who were then required to use additional material and labour to level the ceiling height which resulted from the additional depth required for the steel beam. This prompted discussion within the roadmap sandpit around how to incorporate buildability into the design by improving communication and feedback throughout the supply chain, the difficulties of doing so, and how to 
implement it. Within the roadmap sandpit the timber frame team drew on this example and gave an overview of their information flow throughout a contract, identifying areas where information gets 'lost in translation', thereby reviewing their own processes.

\section{Manufacture}

The success of the processes and practices within the manufacturing phase determine the quality of the timber frame components. However, these processes and practices are dependent on wider supply chain experience of working to a prefabricated project process. As proposed in the business case phase, in a fragmented supply chain the prefabrication process is overlaid onto a traditional construction programme. In many cases, the logic of prefabrication and the just-in-time principles that ensure its success conflict with the existing processes and practices of the supply chain.

To capitalise on the benefits of prefabricated timber frame the alignment of processes and practices is essential in moving from a fragmented to a fully integrated supply chain. Adaptation by both the developer and the timber-frame contractor should be considered to make full integration a viable option. This section expands on a key issue that affected trade progress onsite and how the timber frame contractor capitalised on this feedback to improve the design of their proprietary timber-frame panel. Further considerations are illustrated within figure 1 to show how the project team might move toward a fully integrated supply chain.

\section{Vignette 3: The benefits of supply chain feedback}

Through a process of documenting and discussing trade experience with the timber-frame, in relation to their package requirements, it was found that the service battens installed within the timber frame panels were too shallow, making it difficult for follow-on trades to route and install first fix services. Consequently, the site manager had to retrofit additional $10 \mathrm{~mm}$ strips of timber on the panels where this issues occurred. This onsite problem - the implications of which are further elaborated on within the build-out section - was used by the TF contractor to redesign the standard panelling system produced within the factory to increase depth and ensure consistent quality:

"Instead of using a different sized top plate to studs now we're going to use the same... with the service battens only on the studs that's a different size but now everything is going to one solid timber made panel with service battens round so there's going to be no discrepancies at all

Material suppliers were reviewed to provide service battens at the correct thickness and factory operatives were consulted with to determine the most appropriate configuration of the improved wall based on this supply chain feedback.

Based on the issues raised from onsite data collection supply chain feedback became a central point of discussion within the roadmap forum to project forward and make retrospective assertions as to a 
fragmented supply chain status. Focussing on the difficulty of maintaining consistent engagement with trades highlighting that the scale of problems experienced onsite seem small to trades because they can implement workarounds but at the factory level this feedback is vital to improving the quality of their product and ultimately the progress of the project. As the following comment illustrates:

"It's actually when it gets to site and issues that are raised that may be not fed back to us maybe causes a delay, which puts us in a bad light, if you like, for future contracts. It's that end thing, and it, we're trying to get this across to people. It might seem minute or small for you guys, but to us on the wider spectrum of mass producing, if you like, it can mean a hell of a lot, yeah."

This also prompted discussion around how to engage follow-on trades highlighting that their willingness to feedback and contribute may be dependent on their understanding of the 'logic' of the timber-frame; if they do not fully understand how it should perform, then it is difficult for them to provide constructive feedback.

\section{Installation}

Site activities will determine the success of the installation phase and so communication between the manufacturing team and the site manager is essential. Site-specific constraints should be considered in the previous stages to optimise the design of panels but the progress of manufacture and groundworks are interdependent. For example, if the frame is finished before the site is ready the developer can incur a fee and vice versa in terms of temporary works etc. To avoid these penalties, liaison between the site team and the timber-frame team is vital to ensure accurate intersections between the timberframe, substructure and foundations. As the timber frame consultant describes, the extent of dialogue varies from client to client: "The guy on the site knows exactly where he is with his site schedule. On other occasions we're having to fight tooth and nail"

In the case study project, this proved to be successful; the process of which is described in the following vignette that was fed forward and backward into the roadmap scenarios.

\section{Vignette 4: Substructure and foundation solution - success of soleplate}

Along with the developer, this project was the first that the site manager had been involved in. Having read the industry literature regarding timber frame they realised that site logistics and the substructure are an integral part of a successful installation phase. The tolerances that they normally work with in traditional brick and block are considerably higher and any discrepancies at substructure level can be 'made good' by an expert bricklayer as they complete each course of brickwork. 
An installation sandpit aided this process by discussing soleplate tolerances, along with strategies of ensuring that all construction professionals involved are aware of the specific requirements of the timber-frames being installed.

The sand pit led to extremely accurate intersections, in the words of an experienced bricklayer: "they are the best I've ever worked with". The timber-frame installers were also complimentary about how level the substructure was which led to the rapid installation of the soleplates. The installation sandpit and continuous communication between Site Manager and TF Contractors ensured that the soleplate was ready for the timber frame.

\section{Build-out}

Prefabricated timber-frame construction is intended to reduce the number of interfaces and extent of scope of works between trades onsite. However, attention should be paid to the programming of onsite activities to fully capitalise on this benefit. To do so, build-out tasks and activities need to be well defined to avoid trade overlap and unanticipated tasks that create 'pinch-points' in the project programme. Ongoing review of the project programme should be supported by trade feedback and information technology to improve the management of materials and resources.

\section{Vignette 5: Unanticipated tasks and additional work}

As mentioned in the previous vignettes, the short lead time for the timber-frame meant that the developer had to issue the architects drawings for trades to tender from. At this point the full scope of work packages was not fully defined having the most impact on the carpenters whose workload on the site increased as unanticipated or unaccounted for tasks were identified. These generally revolved around the specification of work packages and making clear the distinction between what would be completed by the timber frame team and what would need to be completed onsite. In one example, the carpenter described the process they had to go through to allow the plasterers to fire-line party walls:

“...the timber frame people hadn't fire lined the gable wall in the loft. So we had to come in and take a lot of the straps out and a lot of the timber out so that the tacker could get up, plasterboard it, fire line it. And then we've had to go back and then put all the battens back and the bracing back that was already done by the timber frame, but I could see that as soon it was going up. I wondered why they didn't put and spandrel panels in that were lined at the time."

In a similar example the carpenter described how the stairs needed to be removed and refitted to, again, allow for the plasterers to fire-line the walls. The reason this had to be done was that the sequencing of trades followed that of a traditional brick and block build - first fix services needed to be able to get up to the first and second floors before the plasterers were scheduled to begin their work package. What this case study example illustrates is the importance of recognising and understanding the effect of activities and decisions made within previous phases. However, for a housebuilder using 
timber frame for the first time the cumulative impact of such issues can have an impact on the overall benefits that supported the business case to build with timber frame in the first instance.

\section{[Insert Figure 2]}

\section{Discussion and Conclusion}

The focus of this paper has been to present the process of creating an empirically informed roadmap of supply chain integration suited to the context of small housebuilders arguing that scenario building should be contextualised and empirically informed. Within this paper, we focussed on SMEs integrating through the construction of timber-frame houses as a basis of contextualising the roadmap. In doing so, we connected current supply chain dynamics across various aspects of construction with projections of what integration could be in the future to open up tangible ways of increasing integration with suppliers of MMC.

In building on work concerning the capacity of small house-building firms to innovate whereby challenges and opportunities are spread across project teams (Abbott et al, 2006; Barrett and Sexton, 2003), and developments in approaches to road mapping that emphasise the importance of context driven flexible scenario planning (Savioz and Blum), this paper has demonstrated some of the potential benefits of creating roadmaps for small-builders implementing MMC. This paper contributes to technology-roadmapping literature and construction innovation literature by countering normative conceptions of roadmapping with a 'force of example' case and by putting forward possible ways such as axis of integration and stagegate sandpints - that structured yet flexible approaches may be operationalised. The sum of which provides a nuanced and theory-laden approach to roadmapping supply chain integration for SME housebuilders adopting MMCs. This has revealed forms of integration that a supply chain may target in order to modify technologies and processes to suit particular contexts. In doing so, we have developed an approach based on adaptability and flexibility in order to facilitate the creation of desired forms of integration based on between project-level objectives and firm capabilities to innovate.

The stage-gate sandpits gave the firms an opportunity to overcome obstacles relating to the development - see substructure and foundation solution - and also a sounding board for options to integrate further. Placing phases - such as the contradictory procurement strategies in the business case - alongside other phases - such as the design process conflict - helped to inform the team how adapting forms of integration in one phase has consequences for others.

Having an axis on integration rather than fixed durations helped to reflect the innovation characteristics of small firms, for example, in our case there was no prospect of the housebuilder 
committing to build all subsequent developments with timber-frame; some projects may be more appropriate than others to utilise timber-frame. Doing so takes into serious consideration how integration happens and positions onsite implications alongside, rather than separate to, capabilities. Illustrating what tasks are required, but also helping to inform how particular processes of construction occur and are adapted across multiple actors and firms; if small housebuilders are to take up MMCs, their dispersed supply-chain needs to be on board in order to contribute to the overall direction in which the firm is directed.

Furthermore, situating supply chain actors within the overall project context helped them to understand some of the complexities of supply chain activities, and in some ways the extent of their jurisdiction and the implications of upstream and downstream activities. This reflexivity was intrinsic to the roadmapping approach presented within this paper which began to open up realistic avenues of integration. Adopting an open table approach to roadmapping meant that scenarios were eradicated just as much as they were created, for example, the discussions surrounding full-scale partnership as a procurement method. In addition, foregrounding the dynamics involved when small-housebuilders take up MMC for the first time focussed more attention on improvements to buildability rather than focussing on the cost of integration. Explicitly engaging with the empirical findings gave the housesbuilder a realistic expectation of how the implementation of MMCs occurs and that directions of innovation are possible rather than whole-scale transitions. Therefore, it is hoped that these findings will inform consequent studies into both innovation and approaches to integration within SMEs. Future research trajectories could involve longitudinal studies over the course of a number of housing projects to analyse the impact of this approach on both the uptake of MMCs and the impact of the routes to integration on project success.

The flexible and adaptable approach taken to the roadmap allows the roadmap to be customised to particular contexts. As such readers applying the approach to a different geographical location - or context in general - will inevitably require activities in the roadmap to be customised. The approach to roadmapping taken suggests a starting point for further adaptation. Hence the major limitation of the study - only focusing on one year of integration between the firms - can be overcome through a longer stretches of research that follows how the firms continue to integrate. Further research could also compare results with other case studies.

\section{References}

Albright, R.E. and Kappel, T.., 2003. Roadmapping in the corporation. Research-Technology Management, 42(2), pp.31-40.

Amer, M. and Daim, T., 2010. Application of technology roadmaps for renewable energy sector. 
Technology Forecast Social Change, 77(8), pp.1355-1370.

Archer, T. and Cole, I., 2016. Profits before Volume? Major housebuilders and the crisis of housing supply, Sheffield Hallam University.

Asibong, C. and Barlow, J., 1997. Barriers to Innovation and Change in the Housebuilding Industry. In Housing Studies Association Conference. York.

Barrett, B. and Sexton, M., 2006. Innovation in small, project-based construction firms. British Journal of Management, 17, pp.331-346.

Broadley, C. et al., 2016. From Participation to Collaboration : Reflections on the co-creation of innovative business ideas. Proceedings of DRS 2016, Design Research Society 50th Anniversary Conference, pp.1-20.

Caetano, M. and Amaral, D.C., 2011. Roadmapping for technology push and partnership: A contribution for open innovation environments. Technovation, 31(7), pp.320-335.

Daim, T.U. and Oliver, T., 2008. Implementing technology roadmap process in the energy services sector: A case study of a government agency. Technological forecasting and social change, 75(5), pp.687-720.

DCLG, 2017. Housing White Paper - Fixing our broken housing market, London.

Flyvberg, B. 2006. Five misunderstandings about case-study research. Qualitative Inquiry, 12(2), 219-245.

Gerdsri, N., Vatananan, R.S. and Dansamasatid, S., 2009. Dealing with the dynamics of technology roadmapping implementation: A case study. Technological forecasting and social change, 76(1), pp.50-60.

Green, M.S. et al., 2017. On-site integration in off-site house construction: chains, flows, and eddies. In Procs 9th Nordic Conference. Gothenburg, Sweden: Construction Researchers on Economics and Organisation in the Nordic region.

Hanson, N.R., 1958. Patterns of discovery : an enquiry into the conceptual foundations of science, Cambridge University Press.

HBF, 2017. Reversing the decline of small housebuilders: Reinvigorating entreprenurialism and buildling more homes, London.

Kappel, T.A., 2001. Persectives on Roadmaps - how organisations talk about the future. The Journal of Product Innovation Management, 18, pp.39-50.

Lee, S. et al., 2009. Business planning based on technological capabilities: Patent analysis for technology-driven roadmapping. Technological forecasting and social change, 76(6), pp.769- 
786.

Lee, S. and Park, Y., 2005. Customization of technology roadmaps according to roadmapping purposes: Overall process and detailed modules. Technological Forecasting and Social Change, 72(5), pp.567-583.

Lichtenthaler, U., 2010. Technology exploitation in the context of open innovation: finding the right “job”for your technology. Technovation, 30(7), pp.429-435.

Loureiro, A.M.V., Borschiver, S. and Coutinho, P.L. de A., 2010. The technology roadmapping method and its usage in Chemistry. Journal of Technology Management and Innovation, 5(3), pp.181-191.

Muscio, A., 2007. The impact of absorptive capacity on SMEs collaboration. Economics of Innovation and New Technology, 16(8), pp.653-668.

Oliveira, M.G. and Rozenfeld, H., 2010. Integrating technology roadmapping and portfolio management at the front-end of new product development. Technological forecasting and social change, 77(8), pp.1339-1354.

Pan, W., Gibb, A.G.F. and Dainty, A.R.J., 2007. Perspectives of UK housebuilders on the use of offsite modern methods of construction. Construction Management and Economics, 25(2), pp.183-194.

Patton, M.Q. (2002), 'Qualitative evaluation and research methods (3rd ed.). Thousand Oaks, CA: Sage Publications, Inc

Paulston, R.G. and Liebman, M., 2016. An Invitation to Postmodern Social Cartography. Comparative Education Review 38(2), pp.215-232.

Phaal, R., Farrukh, C. and Probert, D., 2010. Roadmapping for strategy and innovation. Aligning technology and markets in a dynamic world. University of Cambridge: Institute for Manufacturing.

Phaal, R., Farrukh, C. and Probert, D., 2013. Technology management and roadmapping at the firm level. In M. G. Moehrle, R. Phall, and R. Isenmann, eds. Roadmapping for Strategy and Innovation: Charting the Route to Success. Berlin, Heidelberg: Springer, pp. 13-29.

Phaal, R., Farrukh, C. and Probert, D., 2004. Technology roadmapping - A planning framework for evolution and revolution. Technological Forecasting and Social Change, 71(1-2), pp.5-26.

Probert, D. and Shehabuddeen, N., 1999. Technology road mapping: the issues of managing technology change. International Journal of Technology Management, 17, pp.646-661.

Ritchie, J., and Lewis, J. 2013. Qualitative research practice: a guide for social science students and researchers. London, Sage Publications. 
Rocha, G.V. and Mello, C.H.P., 2016. How to develop technology roadmaps? The case of a Hospital Automation Company. Production, 26(2), pp.345-358.

Savioz, P. and Blum, M., 2002. Strategic forecast tool for SMEs: how the opportunity landscape interacts with business strategy to anticipate technological trends. Technovation, 22(2), pp.91100.

Sexton, M. and Barrett, P., 2003. Appropriate innovation in small construction firms. Construction Management and Economics, 21(6), pp.623-633.

Stonehouse, G. and Pemberton, J., 2002. Strategic Planning in SME's - Some Empirical Findings. Management Decision, 40(9), pp.853-861.

Upstill-Goddard, J., Glass, J., Dainty, A. and Nicholson, I., 2016. Implementing sustainability in small and medium-sized construction firms. Engineering Construction and Architectural Management (09699988), 23(4), p.407 - 427.

Wang, C., Walker, E. and Redmond, J., 2007. Explaining the Lack of Strategic Planning in SMEs: The Importance of Owner Motivation. International Journal of Organizational Behavior, 12(121), pp.1-16.

Wells, R. et al., 2004. Technology roadmapping for a service organization. Research-Technology Management, 47(2), pp.46-51.

Winch, P., 1958. The Idea of a Social Science and its Relation to Philosophy, New York: Routledge. 


\begin{tabular}{|l|l|}
\hline \multicolumn{1}{|c|}{ Firm } & \multicolumn{1}{c|}{ Role } \\
\hline Developer & Director \\
\hline TF Contractor & Sales and Marketing Manager \\
\hline TF Contractor & Senior Estimator \\
\hline TF Contractor & Design team \\
\hline TF Contractor & Purchasing and logistics Manager \\
\hline TF Contractor & Regional Sales Manager \\
\hline TF Contractor & Designer \\
\hline Developer & Site Manager \\
\hline Developer & Assistant site Manager \\
\hline Subcontractor & Brick Layer \\
\hline Subcontractor & Carpenter \\
\hline Subcontractor & Electrician \\
\hline
\end{tabular}


SUPPLY CHAIN STATUS

\section{FEASIBILITY SANDPIT -TIMBER FRAME FOR SMALL HOUSEBUILDERS}

\begin{tabular}{|c|c|c|c|c|c|}
\hline \multirow[t]{2}{*}{ Driver } & \multirow{2}{*}{$\begin{array}{l}\text { Lowest cost and focus on individual } \\
\text { supply chain member profit maxi- } \\
\text { misation }\end{array}$} & Driver & $\begin{array}{l}\text { Transition from lowest cost to added } \\
\text { value }\end{array}$ & Driver & $\begin{array}{l}\text { Focus on value and overall supply } \\
\text { chain profit maximisation }\end{array}$ \\
\hline & & Approach & Moving toward project partnering & Approach & Value-adding partnership \\
\hline Approach & \multirow{3}{*}{$\begin{array}{l}\text { Open/competitive tendering } \\
\text { process } \\
\text { Late stakeholder engagement. }\end{array}$} & \multirow{2}{*}{ Characteristics } & Partnering Agreement & & Partnering Agreements \\
\hline \multirow[t]{2}{*}{ Characteristics } & & & $\begin{array}{l}\text { Objective driven, tactical and } \\
\text { short-term }\end{array}$ & Characteristics & $\begin{array}{l}\text { Longer-term strategic relationships } \\
\text { continuing across multiple projects. }\end{array}$ \\
\hline & & \multirow[t]{2}{*}{ Positives } & \multirow{2}{*}{$\begin{array}{l}\text { Stronger communication channels } \\
\text { between supply chain. } \\
\text { Assess and balance functional } \\
\text { trade-offs. }\end{array}$} & & information \\
\hline Positives & $\begin{array}{l}\text { Cost certainty-that enables cash } \\
\text { flow management }\end{array}$ & & & Positives & $\begin{array}{l}\text { Equitable team relationships. Risks/ } \\
\text { rewards shared over the long-term. } \\
\text { Successes are collectively shared }\end{array}$ \\
\hline Negatives & $\begin{array}{l}\text { Overlaying MMC onto traditional } \\
\text { project processes. }\end{array}$ & Negatives & $\begin{array}{l}\text { Risk associated with unfamiliar } \\
\text { procurement routes }\end{array}$ & Negatives & $\begin{array}{l}\text { Failures are collectively shared. } \\
\text { Perceived lack of flexibility }\end{array}$ \\
\hline
\end{tabular}

\section{DESIGN SANDPIT}

\section{CHARACTERISTICS/PROCESS}

1. Appoint experienced architect

2. Linear design process

- Incompatible design software (rework)

3. Select components from Timber Frame (TF) contractor portfolio

\section{OUtCOMES}

1. Different docs means different interpretation of technical and contractual docs

2. Conflict between standard components used by manufacturers and developer requirements

CHARACTERISTICS/PROCESS

1. Success of IIT principles at risk from limited supply chain experience with the process

2. Factory processes geared towards repeatable and standardised components

3. TF contractor to consult with client/site manager re: build programme (two-way)

4. Material availability dependent on suppliers

OUTCOME

1. Discrepancies between TF and externals (windows/coursing)

2. Disconnect between trade expectations and "logic of frame-expectation of service routes

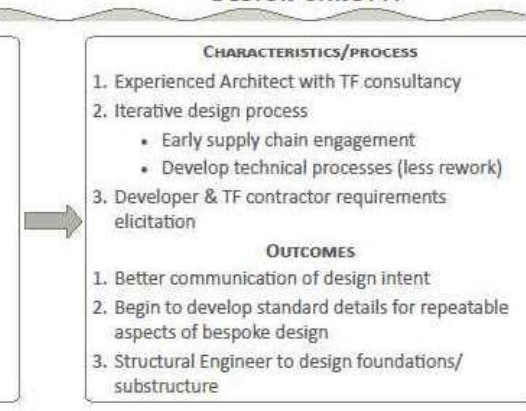
substructure

\begin{tabular}{|c|}
\hline CHARACTERISTICS/PROCESS \\
\hline $\begin{array}{l}\text { 1. Review material suppliers to improve standardised } \\
\text { component design according to project } \\
\text { requirements }\end{array}$ \\
\hline $\begin{array}{l}\text { 2. Reassess factory processes to incorporate: Late } \\
\text { changes/Service routes/Fit-out fixtures }\end{array}$ \\
\hline $\begin{array}{l}\text { 3. TF contractors to advise on specific plant } \\
\text { requirements based on scope of works }\end{array}$ \\
\hline OUTCOMES \\
\hline 1. Continuity of coursing \& window tolerances \\
\hline $\begin{array}{l}\text { 2. Communication of specific 'logic' of frame } \\
\text { (business case alignment) }\end{array}$ \\
\hline 3. Improved quality assurance process \\
\hline
\end{tabular}

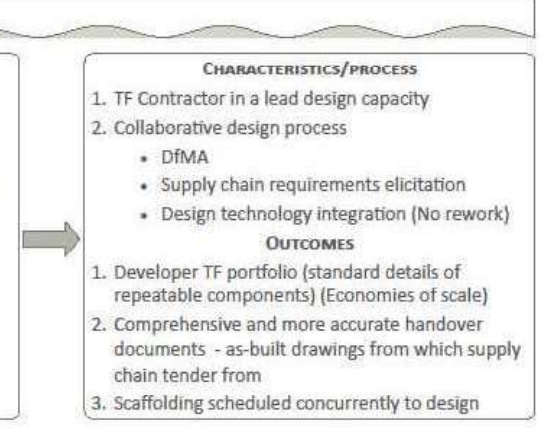

3. Scaffolding scheduled concurrently to design

\section{CHARACTERISTICS/PROCESS}

1. Systematic review of factory processes to accommodate changing supply chain requirements

2. Manufacture according to supply chain requirements

3. TF contractor to liaise with follow-on trades OUTCOMES

1. Integrated fixing fittings for installation -

Pre-drilling holes for lifting and lashing equipment

2. Systematic review of supplier base

3. Library of client components for IIT manufacture

4. Improved sequencing
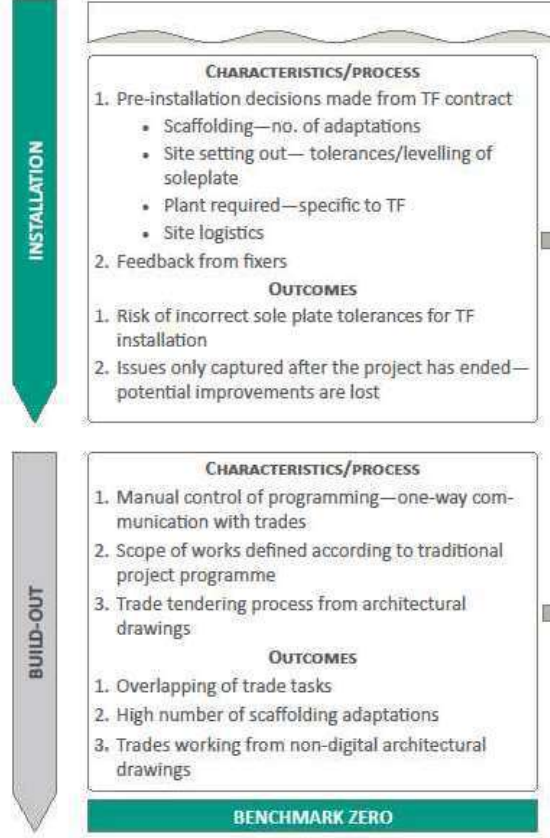

\section{ChARACTERISTICS/PROCESS}

1. Manual control of programming-one-way communication with trades

2. Scope of works defined according to traditional project programme

3. Trade tendering process from architectural drawings

1. Overlapping of tratcomes

. High no trade tasks

2. High number of scaffolding adaptations

3. Trades working from non-digital architectural drawings

\section{INSTALLATION SANDPIT \\ CHARACTERISTICS/Process
1. Ongoing communication between TF contractor . Ongoing communication between TF contractor completion and TF design progress \\ 2. Feedback from supply chain \\ 3. Improved handover process-project notes \& satisfaction notes \\ 1. Co-contracted plant-hire-rationalising resources \\ 2. Procurement of groundworkers with TF specific skills, tech and experience \\ 3. Early issue of soleplate drawings to crosscheck groundworks progress}

CHARACTERISTICS/PRocess
1. Engage TF contractor as consuitant to sequence build-out

2. Digital programme to support adaptive programming and oversee supply chain resourcing

3. Trade procurement process from TF drawings OUTCOMES

1. Scope of works specific to TF requirements

2. Reduction in interfaces and scope of works on site

3. Trade feedback to support adaptive programming

OVERALL PROGRAMME SAVING OF 5 DAYS

\section{ChARACTERISTICS/PROCESS}

1. Digital building models to plan site logistics

2. Automated system with tracking-RFID-dispatch software to ensure all components are sent

3. Negotiated solution amongst supply chain to define substructure requirements Outcomes

1. Plant hire rationalised according to current project portfolio

2. Reliable and trusted supply chain to deliver Reliable and

substructure 3. Supply chain lished drawings

\section{ChARACTERISTICS/PROCESS}

1. Prequalification of trades

2. Negotiated project scheduling - trades to contribute to the design and project planning process

3. Real-time construction management systems

4. Tendering process based of total scope of project OUtcomes

1. Digital snagging list for lessons learnt capture

2. Reliable and trusted supply chain

3. Improved management of materials and resources eliminating trade overlap 


\section{SUPPLY CHAIN STATUS}

